\title{
Abnormality of Odd-Numbered Long-Chain Fatty Acids in Erythrocyte Membrane Lipids from Patients with Disorders of Propionate Metabolism
}

\author{
U. WENDEL \\ Kinderklinik, Universität Düsseldorf, D-4000 Düsseldorf, Federal Republic of Germany
}

\begin{abstract}
In propionic acidemia and methylmalonic aciduria, disorders of propionate catabolism, excess intracellular propionyl-CoA leads to an enhanced synthesis of odd-numbered long-chain fatty acids. Red cell membrane lipids of patients with these disorders contain pentadecanoic, heptadecanoic, and heptadecenoic acids in excess of normal levels. The odd-numbered long-chain fatty acid content may reflect individual differences in severity of these disorders as well as the degree of effective dietary control. It might be a useful long term parameter for determining the effectiveness of clinical management. ( $P e$ diatr Res 25:147-150, 1989)
\end{abstract}

Abbreviations
PA, propionic acidemia
MMA, methylmalonic aciduria
OLCFA, odd-numbered long-chain fatty acids
PC, phosphatidylcholine
PE, phosphatidylethanolamine

In PA (McKusick 23 200) and MMA (McKusick 25 100), the catabolic pathway for propionyl-CoA is impeded, leading to an increased equilibrium concentration of propionyl-CoA in cells. The enlarged intramitochondrial pool of propionyl-CoA causes inhibitory effects on selected mitochondrial functions (1). Patients with each of these disorders do not properly metabolize isoleucine, valine, methionine, and threonine, the amino acid precursors of propionyl-CoA. In addition, during oxidation of odd numbered fatty acids, propionyl-CoA is formed.

There is a wide spectrum of clinical presentation of both disorders (2-4). Clinical prognosis and long-term outcome depend essentially on metabolic control. Notwithstanding excellent dietary management with an optimally restricted intake of the respective amino acid precursors, a minimum of toxic intermediates accumulates in each patient $(5,6)$. Determination of exactly this minimal level in each individual is cumbersome and not easily managed in practice. There is agreement that measurements of metabolites (these are plasma propionate, urinary methylmalonate, 3-methylpropionate, methylcitrate) have not consistently yielded useful information for the assessment of the clinical progress (2) and that an appropriate biochemical parameter is lacking so far.

There is relative abundance of odd-numbered fatty acids in

Received May 23, 1988; accepted September 13, 1988.

Correspondence U. Wendel, Universität Düsseldorf, Moorenstr. 5, D-4000 Düsseldorf, Federal Republic of Germany.

Supported by Grant We 614/5-1 from the Deutsche Forschungsgemeinschaft. body lipids of patients with defective propionate metabolism. This knowledge derives from the time of the discovery of these disorders (7-10) but has not been followed up. In the present study, the relative amounts of OLCFA in erythrocyte membrane lipids from patients with propionic acidemia and methylmalonic aciduria were evaluated. A relationship between the clinical course of the disorders and the OLCFA levels in erythrocytes could be established. Thus, OLCFA might be a valuable parameter for assessment of the level of control in disorders of propionate metabolism.

\section{PATIENTS AND METHODS}

Patients. Patients with PA, MMA, and inherited disorders not affecting propionate metabolism (organic acidurias) were studied. Details of the patients are listed in Table 1.

Methods. Venous blood samples $(3-5 \mathrm{ml})$ were collected in EDTA tubes and sent to Düsseldorf within $48 \mathrm{~h}$.

In Düsseldorf erythrocytes were isolated and washed as described (11) and stored at $-20^{\circ} \mathrm{C}$ until analysis. The workup of the samples-extraction of membrane lipids, separation into the $\mathrm{PE}$ and $\mathrm{PC}$ fractions by thin-layer chromatography, subsequent base-catalyzed transesterification of the fatty acids using sodium methoxide as well as analysis of the fatty acid methyl esters by capillary column gas liquid chromatography was exactly as we have described (11). Fatty acids of 14-22 carbon length were identified by comparison with authentic standards. In long term and within-day precision studies, a coefficient of variation of $<3 \%$ was found for all major fatty acids and exceeded $10 \%$ in fatty acids present in trace amounts (11).

In each sample, the proportions of the individual OLCFA15 and 17 carbon saturated and 17 carbon monounsaturated fatty acids (C 15:0, C 17:0, C 17:1) - as well as their sums were calculated and expressed as a percentage of the total C 14-C 22 fatty acids in the sample. The data are given for total membrane lipids as well as for their PC and PE fractions.

\section{RESULTS}

As shown in Table 2, the OLCFA (pentadecanoic, heptadecanoic, and heptadecenoic acids) in red cell membrane lipids of most PA and MMA patients studied were in excess of normal levels. Subjects with inherited disorders not affecting propionate metabolism on comparable diets with respect to protein restriction and type of ingested fat showed essentially the same OLCFA pattern as controls.

Among the two membrane phospholipids analyzed, the PC fraction, which normally contains the largest amounts of saturated and monounsaturated fatty acids, also contained the highest levels of OLCFA. In either phospholipid as well as in total 
Table 1. Details of patients with $P A$ and $M A^{*}$

\begin{tabular}{|c|c|c|c|c|c|c|c|}
\hline \multicolumn{8}{|c|}{ Patients with PA } \\
\hline Patient & $\begin{array}{c}\text { Type of } \\
\text { presentation }\end{array}$ & Age & $\begin{array}{c}\text { Ketoacidotic } \\
\text { episodes/y }\end{array}$ & $\begin{array}{c}\begin{array}{c}\text { Level of } \\
\text { development }\end{array} \\
\end{array}$ & $\begin{array}{l}\text { Natural } \\
\text { protein } \\
\text { intake } \\
(\mathrm{g} / \mathrm{kg} / \mathrm{d})\end{array}$ & Supplements $\dagger$ & $\begin{array}{c}\text { Remarks; } \\
\text { quality of } \\
\text { control }\end{array}$ \\
\hline $1 \mathrm{YA}$ & Neonatal & $3 \mathrm{y}, 9 \mathrm{mo}$ & 3-4 (severe) & Severely retarded & 0.7 & $\mathrm{AA}$ & Poor \\
\hline $2 \mathrm{MG}$ & Neonatal & $7 \mathrm{y}$ & $\begin{array}{l}\text { Frequently ke- } \\
\text { totic }\end{array}$ & Mildly retarded & 0.7 & $\mathrm{AA}$ & Poor \\
\hline $3 \mathrm{SK}$ & Neonatal & $7 \mathrm{mo}$ & 2 & Retarded & 1.1 & $\mathrm{AA}, \mathrm{CARN}$ & Unstable \\
\hline $4 \mathrm{MB}$ & Neonatal & $11 \mathrm{~d}$ & & & 0.7 & AA, CARN & Initial therapy \\
\hline $5 \mathrm{EE}$ & Late & $26 \mathrm{mo}$ & 0 & Low normal & 1.2 & $\mathrm{AA}$ & Fair \\
\hline $6 \mathrm{MR}$ & Neonatal & 2 y, 9 mo & $\begin{array}{l}6 \text { mild de- } \\
\text { rangements }\end{array}$ & Retarded & 0.8 & $\mathrm{AA}, \mathrm{CARN}$ & Good \\
\hline $7 \mathrm{RP}$ & Late & $20 y$ & 0 & $\begin{array}{l}\text { Mildly retarded, } \\
\text { spasticity }\end{array}$ & 0.6 & CARN & Good \\
\hline $8 \mathrm{SH}$ & Late & $21 \mathrm{mo}$ & 0 & Low normal & 1.5 & & Excellent \\
\hline $9 \mathrm{LdB}$ & Neonatal & $8 y$ & 0 & Normal & 0.8 & AA, CARN, BIOT & Excellent \\
\hline $10 \mathrm{HC}$ & Late & $7 y$ & 0 & $\begin{array}{l}\text { Low normal, dys- } \\
\text { kinesia }\end{array}$ & 1.0 & & Excellent \\
\hline $11 \mathrm{AN}$ & $\begin{array}{l}\text { Biotinidase defi- } \\
\text { ciency }\end{array}$ & $3 \mathrm{mo}$ & 0 & Normal & Normal & & Excellent \\
\hline \multicolumn{8}{|c|}{ Patients with MA } \\
\hline Patient & $\begin{array}{c}\text { Enzyme } \\
\text { activity/type }\end{array}$ & Age & $\begin{array}{c}\text { Ketoacidotic } \\
\text { episodes/y }\end{array}$ & $\begin{array}{c}\text { Level of } \\
\text { development }\end{array}$ & $\begin{array}{l}\text { Natural } \\
\text { protein } \\
\text { intake } \\
(\mathrm{g} / \mathrm{kg} / \mathrm{d})\end{array}$ & Supplements & $\begin{array}{l}\text { Remarks; } \\
\text { quality of } \\
\text { control }\end{array}$ \\
\hline $12 \mathrm{AS}$ & $\mathrm{Mut}^{\circ}$ & $4 \mathrm{y}, 10 \mathrm{mo}$ & $2-4$ & Severely retarded & 1.0 & $\mathrm{AA}, \mathrm{CARN}$ & Poor \\
\hline $13 \mathrm{LR}$ & Severe & $3 \mathrm{y}$ & $\begin{array}{l}>10, \text { frequently } \\
\text { ketotic }\end{array}$ & Severely retarded & 0.8 & $\mathrm{AA}$ & Poor, unstable \\
\hline $14 \mathrm{TS}$ & $\mathrm{Mut}^{\circ}$ & $2 y$ & $\begin{array}{l}\text { 4, frequently } \\
\text { ketotic }\end{array}$ & Retarded & 1.2 & CARN & Poor, unstable \\
\hline $15 \mathrm{SM}$ & Severe & $3 \mathrm{y}, 2 \mathrm{mo}$ & Frequent & $\begin{array}{l}\text { Retarded, severe } \\
\text { visual impair- } \\
\text { ment }\end{array}$ & 0.8 & $\mathrm{AA}$ & Fair \\
\hline $16 \mathrm{CW}$ & $\mathrm{Mut}^{\circ}$ & $2 \mathrm{y}, 4 \mathrm{mo}$ & 2 & Retarded & 1.0 & $\mathrm{AA}, \mathrm{CARN}$ & Good \\
\hline $17 \mathrm{MS}$ & $\mathrm{Mut}^{\circ}$ & $12 \mathrm{y}$ & 0 & Mentally retarded & 0.4 & AA, CARN & Good \\
\hline $18 \mathrm{MV}$ & Severe & $18 \mathrm{mo}$ & 0 & Low normal & 1.0 & $\mathrm{AA}$ & Good \\
\hline $19 \mathrm{BS}$ & Severe & $16 y$ & 0 & $\begin{array}{l}\text { Mentally normal, } \\
\text { paraplegia }\end{array}$ & 0.5 & $\mathrm{AA}$ & Good \\
\hline $20 \mathrm{PD}$ & Severe & $6 \mathrm{y}, 4 \mathrm{mo}$ & 1 & $\begin{array}{l}\text { Attends regular } \\
\text { school }\end{array}$ & 0.8 & $\mathrm{AA}$ & Good \\
\hline $21 \mathrm{BSch}$ & Severe & $5 \mathrm{y}, 2 \mathrm{mo}$ & $1-2$ mild & Low normal & 1.2 & & Good \\
\hline $22 \mathrm{HF}$ & CBL-dependency & $18 \mathrm{mo}$ & 0 & Normal & 2.0 & CBL & Excellent \\
\hline $23 \mathrm{MvR}$ & CBL-B-mutant & $18 \mathrm{y}$ & 0 & Normal & Low & $\mathrm{CBL}$ & Excellent \\
\hline $24 \mathrm{SB}$ & Severe & 3 y, 4 mo & 0 & $\begin{array}{l}\text { Retarded, } 18 \text { mo } \\
\text { brain infarction }\end{array}$ & 1.0 & & Excellent \\
\hline
\end{tabular}

* Other organicacidurias: patient 25 , isovaleric acidemia; patients 26,27 , glutaric aciduria I; patient 28 , medium-chain acyl-CoA dehydrogenase deficiency.

$\dagger$ AA, essential amino acids; CARN, carnitine; BIOT, biotin; CBL, cobalamin.

membrane lipids, the amount of heptadecanoic (C 17:0) acid was highest, followed by pentadecanoic (C 15:0) and heptadecenoic (C 17:1) acids. We did not regularly observe increased amounts of odd-numbered fatty acids with 19 or 21 carbon atoms. The extent of desaturation of heptadecanoic acid, as reflected by the $\mathrm{C} 17: 0 / \mathrm{C}$ 17:1 ratio, was similar in the various phospholipids. The percentage of OLCFA in total red cell lipids roughly equaled the half value of the sum of percentages in $\mathrm{PE}$ and PC.

In Figure 1, the percentages of the 15 and 17 carbon fatty acids are shown for different patients. Red cell membrane lipids from patients with late onset PA (patients 5, 7, 8, and 10) contained less OLCFA than those from patients who presented in the neonatal period. Excessive amounts of OLCFA (up to 7\% of the total fatty acids) were measured in red cell lipids in patients 1 and 2, who were classified as clinically unstable and poorly controlled. High OLCFA levels (approximately $4 \%$ of the total fatty acids) were already present in red cell lipids of a newborn with PA (patient 4). In a biotinidase-deficient patient on biotin therapy (patient 11), the OLCFA pattern was normal.

Patients 22 and 23, who had vitamin $B_{12}$-responsive MMA, showed a normal OLCFA pattern. In each of the other $11 \mathrm{MMA}$ patients, (most of them of the mut ${ }^{\circ}$-class) the OLCFA levels correlated well with metabolic control. In this respect, the samples of five MMA patients (patients 13, 15, 20, 21, and 24) from the same hospital in London were of great value because gradation into good (patients 20,21, and 24), fair (patient 15), and poor (patient 13) control was undertaken by only one expert. 
Table 2. Odd-numbered fatty acids (C 15:0, C 17:0, C 17:1) in erythrocyte membrane lipids (percentage of total fatty acids)*

\begin{tabular}{|c|c|c|c|c|}
\hline & C $15: 0$ & C 17:0 & C $17: 1$ & Sum \\
\hline \multicolumn{5}{|l|}{ Total lipids } \\
\hline Controls $(n=75)$, mean $_{\text {range }} \pm \mathrm{SD}$ & $\begin{array}{l}0.20 \pm 0.06 \\
(0.09-0.47)\end{array}$ & $\begin{array}{l}0.42 \pm 0.06 \\
(0.31-0.6)\end{array}$ & $\begin{array}{r}0.07 \pm 0.03 \\
(0-0.16)\end{array}$ & $\begin{array}{l}0.70 \pm 0.12 \\
(0.46-1.09)\end{array}$ \\
\hline \multicolumn{5}{|l|}{ PA } \\
\hline Patient 1 & 1.75 & 2.78 & 0.27 & 4.80 \\
\hline Patient 5 & 0.68 & 1.05 & 0.13 & 1.86 \\
\hline Patient 7 & 0.31 & 0.50 & 0.05 & 0.86 \\
\hline \multicolumn{5}{|l|}{$\mathrm{MA}$} \\
\hline Patient 12 & 1.60 & 2.18 & 0.28 & 4.06 \\
\hline Patient 15 & 0.87 & 1.34 & 0.23 & 2.44 \\
\hline Patient 22 & 0.27 & 0.40 & 0.05 & 0.72 \\
\hline \multicolumn{5}{|l|}{$\mathrm{PE}$} \\
\hline Controls $(n=75), \underset{\text { range }}{\text { mean }} \pm \mathrm{SD}$ & $\begin{array}{l}0.19 \pm 0.08 \\
(0.07-0.47)\end{array}$ & $\begin{array}{l}0.38 \pm 0.08 \\
(0.24-0.75)\end{array}$ & $\begin{array}{l}0.10 \pm 0.09 \\
(0.00-0.68)\end{array}$ & $\begin{array}{l}0.67 \pm 0.17 \\
(0.37-1.21)\end{array}$ \\
\hline \multicolumn{5}{|l|}{$\mathrm{PA}$} \\
\hline Patient 1 & 0.51 & 1.72 & 0.20 & 2.43 \\
\hline Patient 5 & 0.48 & 0.80 & 0.21 & 1.49 \\
\hline Patient 7 & 0.19 & 0.48 & 0.09 & 0.76 \\
\hline \multicolumn{5}{|l|}{$\mathrm{MA}$} \\
\hline Patient 12 & 0.69 & 1.34 & 0.25 & 2.28 \\
\hline Patient 15 & 0.51 & 0.91 & 0.10 & 1.52 \\
\hline Patient 22 & 0.13 & 0.28 & 0.05 & 0.46 \\
\hline \multicolumn{5}{|l|}{ PC } \\
\hline Controls $(n=75), \underset{\text { mean }}{\text { range }} \pm \mathrm{SD}$ & $\begin{array}{l}0.36 \pm 0.12 \\
(0.16-0.78)\end{array}$ & $\begin{array}{l}0.61 \pm 0.09 \\
(0.41-0.91)\end{array}$ & $\begin{array}{r}0.12 \pm 0.06 \\
(0.0-0.37)\end{array}$ & $\begin{array}{l}1.07 \pm 0.23 \\
(0.61-1.70)\end{array}$ \\
\hline \multicolumn{5}{|l|}{ PA } \\
\hline Patient 1 & 2.83 & 3.44 & 0.28 & 6.55 \\
\hline Patient 5 & 1.06 & 1.27 & 0.17 & 2.50 \\
\hline Patient 7 & 0.57 & 0.73 & 0.08 & 1.38 \\
\hline \multicolumn{5}{|l|}{$\mathrm{MA}$} \\
\hline Patient 12 & 2.40 & 3.22 & 0.39 & 6.01 \\
\hline Patient 15 & 1.66 & 1.81 & 0.14 & 3.61 \\
\hline Patient 22 & 0.35 & 0.55 & 0.08 & 0.98 \\
\hline
\end{tabular}

* Odd-numbered long-chain fatty acids (expressed as a percentage of the total C 14-C 22 fatty acids) in erythrocyte phospholipids from controls ( 75 children, aged 1-15 y, admitted to hospital for elective surgery) and sclected PA and MMA patients with high, intermediate, and low oddnumbered fatty acid content in lipids.

Concerning peak values of the OLCFA, no significant differences were observed between patients with PA and MMA.

Figure 2 illustrates that the percentages of OLCFA in erythrocyte lipids are not fixed in the same patient but are changing with level of metabolic control. In patient 12 , efforts were made to improve metabolic control during the observed time period. As a consequence, he showed a continuous increase in length, weight, and development, which had ceased in the preceding year. However, he later experienced a severe ketoacidotic episode followed by a rapid increase in erythrocyte OLCFA content, which did not return to previous values for 4-6 wk.

\section{DISCUSSION}

In disorders of propionate metabolism, excess amounts of intramitochondrial/intracellular propionyl-CoA occur. In alternative catabolic reactions, certain abnormal organic acids are formed $(12,13)$, which appear in blood and are excreted in urine. In addition to these catabolic mechanisms, propionyl-CoA can replace acetyl-CoA as "primer" for de novo long-chain fatty acid synthesis in the cytosol (14), leading to the formation of oddnumbered fatty acids (15-17).

The principle of management of these disorders is to maintain each patient at his or her minimal level of metabolite accumulation. In that respect. propionate determination in plasma might best reflect on short term the actual metabolic situation.

Our search for more stable indicators of metabolic control was based on the hypothesis that OLCFA synthesis reflects the increased intracellular propionyl-CoA concentrations and that incorporation of OLCFA into lipids, as a substitute for even numbered fatty acids, is proportional to the amounts produced. Our data support such a concept in a number of subjects with $\mathrm{PA}$ and MMA.

Excess intracellular propionyl-CoA leads to an enhanced synthesis, predominantly of the 15 and 17 carbon fatty acids, whereas production of fatty acids with more than 17 carbon atoms is barely increased. The findings indicate a relationship between the abnormality of OLCFA in red cell lipids and the severity of a given disorder. Seriously affected subjects show a direct relationship between the OLCFA levels and the quality of metabolic control. This is also true for long term evaluation of an individual patient.

The two phospholipids PE and PC are asymmetrically localized in the red cell membrane. PE is almost exclusively localized in the inner, $\mathrm{PC}$ is mainly present in the outer leaflet of the membrane bilayer. For purposes of evaluation, the $\mathrm{PC}$ fraction seems to be more sensitive than the PE fraction. However, total red cell lipids can also be used without any reduction in reliability and with the advantage that the lipid extract can be directly analyzed. Turnover rates of phospholipids-in membranes and in plasma-are generally low (18). This might explain the rather sluggish alterations observed in the erythrocyte OLCFA levels after acute events in the patient's clinical course, which are obviously accompanied by changes in the propionyl-CoA pro- 

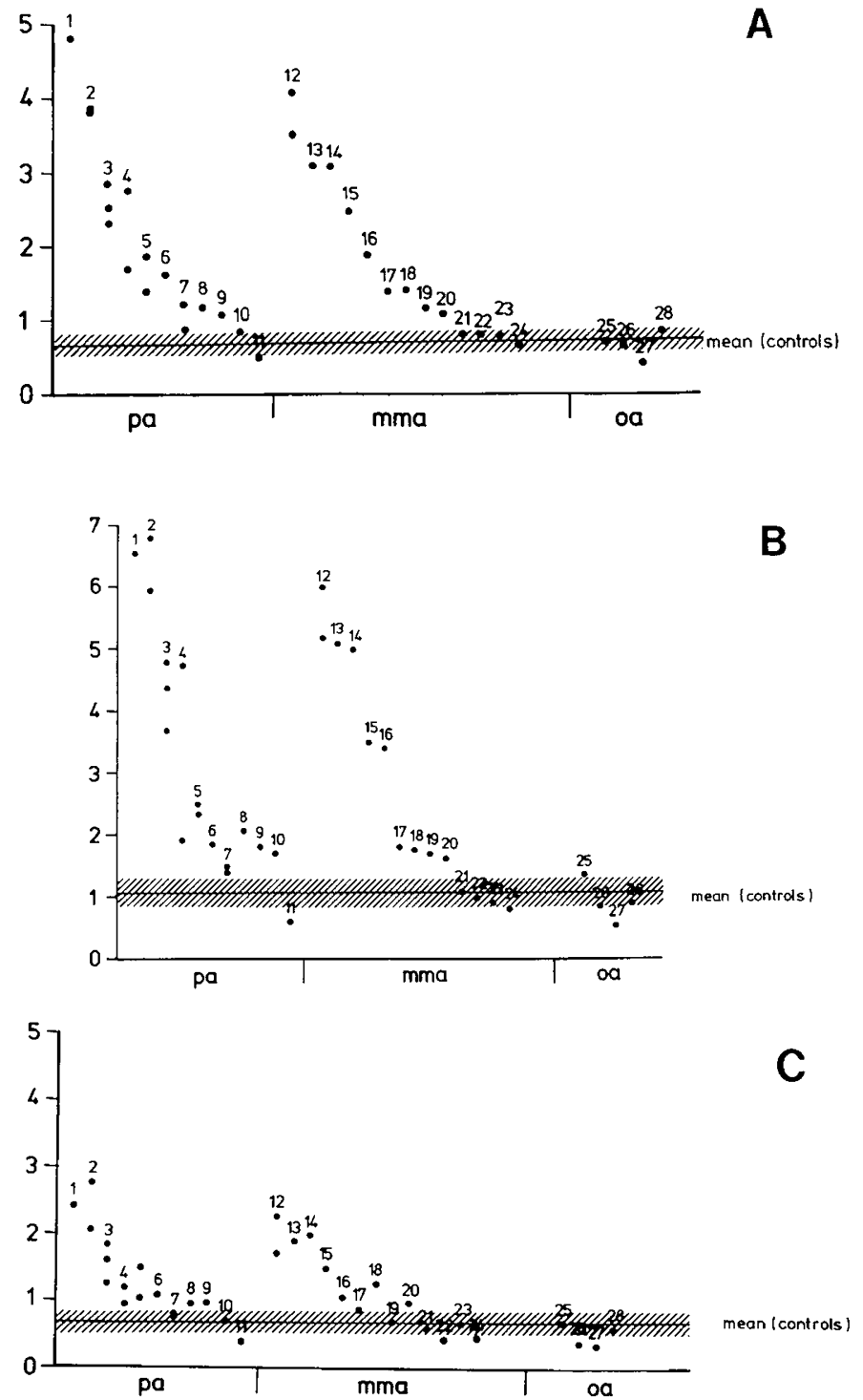

Fig. 1. Percentages of OLCFA (C 15:0, C 17:0, and C 17:1) of the total C 14-C 22 fatty acids in total lipids $(A), \mathrm{PC}(B)$, and PE $(C)$ of erythrocyte membranes for the different subjects. OA, other organicacidurias. For patient's number see Table 1 . $\bullet$, data from one patient at different occasions; 四, mean \pm SD for normal controls $(n=75)$.

duction in the organism. In preliminary studies, the OLCFA levels of different plasma lipid fractions paralleled that in erythrocytes, indicating that the relations between red cell and plasma lipids are important for the formation of the lipid patterns in red cells.

The presented data suggest that the level of odd-numbered fatty acids in red cell membranes may reflect individual differences in severity of the disorders as well as the degree of effective dietary control. It might be a useful indicator of severity and difficulty of control of individual patients and hence a possible indicator of prognosis.

Acknowledgments. I thank Drs. Brodehl and Schweitzer, Hannover (1); Geltinger, Landshut (1); Hirsch, Celle (1); Hecker, Stuttgart; Leupold, Ulm (1); Marg, Bremen (1); Otten, Gießen (1); Przyrembel, Rotterdam (2); Schmidt, Heidelberg (2); Sperl, Innsbruck (3); and Leonard, London (9) for providing blood samples from their patients (number of patients in parentheses) and for providing clinical data. I thank Mrs. E. Diekmann for laboratory assistance and Dr. C. Bachmann, Lausanne, for discussion of the manuscript.

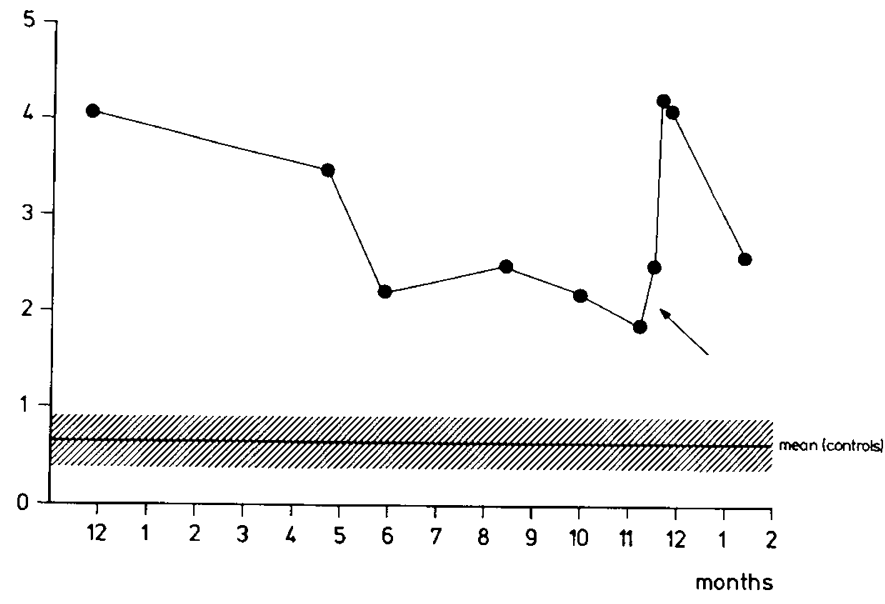

Fig. 2. Content of OLCFA in erythrocyte membrane lipids from patient 12 , suffering from methylmalonic aciduria. When he approached the age of 4 y, 6 mo, growth in length and weight ceased for 18 mo due to clinical instability and poor dietary control at home. For a total of 4 mo of the next 10 mo, he lived on the ward where his clinical condition clearly improved. Arrow, severe ketoacidotic episode. Rapid rise of erythrocyte OLCFA level within 5 days. Return to previous levels was delayed for more than $4 \mathrm{wk}$.

\section{REFERENCES}

1. Rosenberg LE 1983 Disorders of propionate and methylmalonate metabolism. In: Stanbury JB, Wyngaarden JB, Fredrickson DS, Goldstein JL, Brown MS (eds) The Metabolic Basis of Inherited Disease, 5th ed. McGraw-Hill, New York, pp 474-497

2. Wolf B, Hsia YE, Sweetman L, Gravel R, Harris DJ, Nyhan WL 1981 Propionic acidemia: a clinical update. J Pediatr 99:835-846

3. Matsui SM, Mahoney MJ, Rosenberg LE 1983 The natural history of the inherited methylmalonic acidemias. N Engl J Med 308:857-861

4. Leonard JV, Daish P, Naughten ER, Bartlett K 1984 The management and long term outcome of organic acidaemias. J Inherited Metab Dis 7 (suppl 1):13-17

5. Nyhan WL 1985 Disorders of propionate metabolism. In: Bickel H, Wachtel U (eds) Inherited Diseases of Amino Acid Metabolism: Recent Progress in the Understanding, Recognition and Management. Thieme, Stuttgart, pp 363-378

6. Kelts DG, Ney D, Bay C, Saudybray J-M, Nyhan WL 1985 Studies on requirements for amino acids in infants with disorders of amino acid metabolism: I: effect of alanine. Pediatr Res 19:86-91

7. Hommes FA, Kuipers JRG, Elema JD, Jansen JF, Jonxis JHP 1068 Propionicacidemia, a new inborn error of metabolism. Pediat Res 2:519-524

8. Gompertz D, Storrs CN, Bau DCK, Peters TJ, Hughes EA 1970 Localisation of enzymic defect in propionicacidaemia. Lancet 1:1140-1143

9. Gompertz D 1971 The distribution of 17 carbon fatty acids in the liver of a child with propionicacidaemia. Lipids 6:576-580

10. Kishimoto Y, Williams M, Moser HW, Hignite C, Biemann K 1973 Branchedchain and odd-numbered fatty acids and aldehydes in the nervous system of a patient with deranged vitamin $B_{12}$ metabolism. J Lipid Res 14:69-77

11. Laryea MD, Cieslicki P, Diekmann E, Wendel U 1988 Analysis of the fatty acid composition of erythrocyte phospholipids by a base catalyzed transesterification method-prevention of formation of dimethylacetals. Clin Chim Acta $171: 11-18$

12. Ando T, Rasmussen K, Nyhan WL, Hull D 1972 3-Hydroxypropionate: significance of $\beta$-oxidation of propionate in patients with propionic acidemia and methylmalonic acidemia. Proc Natl Acad Sci USA 69:2807-2811

13. Ando T, Rasmussen K, Wright JM, Nyhan WL 1972 Isolation and identification of methylcitrate, a major metabolic product of propionate in patients with propionic acidemia. J Biol Chem 247:2200-2204

14. Lynen F, Hopper-Kessel I, Eggerer H 1964 Zur Biochemie der Fettsäure: III Die Fettsäuresynthese der Hefe und die Bildung enzymgebundener Acetessigsäure. Biochem Z 340:95-99

15. Hajra AK, Radin NS 1962 Biosynthesis of the cerebroside odd-numbered fatty acid. J Lipid Res 3:327-332

16. Oizumi J, Giudici TA, Ng WG, Shaw KNF, Donnell GN 1981 Propionate metabolism by cultured skin fibroblasts from normal individuals and patients with methylmalonicaciduria and propionicacidemia. Biochem Med 26:2840

17. Giudici TA, Chen RG, Oizumi J, Shaw KNF, Ng WG, Donnell GN 1986 Methylmalonic and propionic acidemias: lipid profiles of normal and affected human skin fibroblasts incubated with $1-{ }^{14} \mathrm{C}$ propionate. Biochem Med Metab Biol 35:384-398

18. Wirtz KWA 1974 Transfer of phospholipids between membranes. Biochim Biophys Acta 344:95-117 